\title{
Contract production as a method to reduce welfare loss caused by market uncertainty of seed potato
}

\author{
Jussi Tuomisto \\ MTT Agrifood Research Finland, Economic Research, Luutnantintie 13, FI-00410 Helsinki, Finland, \\ e-mail: jussi.tuomisto@mtt.fi
}

\begin{abstract}
The aim of this study is to show whether contract production between seed and food potato producers lessens market uncertainty, reduce welfare losses for both parties and increase efficiency in the entire potato chain. These problems were approached from the point of view of the principal-agent theory combined with different contract models. Results indicate that no contract model provided seed potato producers with average positive net profits, and profitability ratios for seed potato farms stayed below one. The results indicate that seed potato producers trading on a fixed-price and pre-emptive market could sell their seed potato for 13 per cent less than on a transaction market, but with equal net profits. The more consistent supply chain leads to less market uncertainty. If the food potato producer was not party to the contract, there was no marked decrease in market uncertainty. With contract production the needs of contract parties could be controlled, but it will be up to the objectives of the party offering the contract, which party in the potato chain most benefits from the contract production.
\end{abstract}

Key-words: contract farming, potatoes, vertical coordination, principal-agent theory, supply, markets, contracts, profitability

\section{Introduction}

The use of high-quality seed potato is an important factor when striving for good potato yield and highquality food potatoes are desired (Tuomisto 2003). The food potato producer can either use certified seed potato in planting or supplement the farm's own seed with the certified seed potato. The sizes of potato crops fluctuate annually. The yield of the potato crop has a strong impact on the price of food potato and on the demand of seed potato. According to Jalonoja (2001), when the potato crop is increased by 10 percent, the potato price decreases by 20 percent. As the price of potato decreases, the food potato producer will be more inclined toward using the relatively less expensive seed of the farm for planting than purchasing certified seed (Redman 
and Redman 1981, Gravelle and Rees 1992). When the price of potato is high, food potato producers tend to sell all potatoes as food potatoes and purchase all seed from seed potato producers. Therefore, the demand for certified seed varies, causing the most demanded seed potatoes to be sold out in certain years, while there is excess supply of seed potatoes in other years. In case of excess supply, potatoes that qualify as seed potato must be sold as food potato or waste potato at a price lower than the production cost, which, in turn, means higher seed potato prices to the food potato producers.

Numerous researchers have shown that variability in profits of market participants has been prevalent in commodity marketing chains in recent years (Knoeber and Thurman 1995, Martin 1997). For example Anderson (1973) used the variance of an economic variable as a proxy for risk regarding that variable. Building on Anderson's notation of risk, Kuwornu et al. (1994) conceptualised risk shifting in Dutch potato marketing channels as changes in the variance of the profit of one stage (farmers) relative to changes in the variance of the profit of another stage (marketing firms). Kuwornu et al. (1994) examined risk shifting in a food supply chain between the farmers (agent) and the marketing firms (principal) by applying the classic agency model to a sector level time-series data set. They investigated risk shifting in a channel for two cases: the case when trading futures contracts, and the case without futures trade.

The aim of this study is to show whether contract production between seed and food potato producers would reduce market uncertainty, improve the benefits to the parties of seed potato trade and increase the overall efficiency of the potato chain. The aim was to identify the central problems in the seed potato market, discuss the meaning and extent of collaboration and determine how the price risk and market uncertainty can be reduced with contracts. It was also studied how contract production can be used to develop incentives that would create positive effects for the parties. These problems were approached from the point of view of the principal-agent theory combined with different contract models (Salanié 1997).

\section{Data}

The research data for the study was collected from representatives of different varieties of seed potato and from seed potato marketing companies. The primary data for the research were obtained by means of depth-interviewing the companies Northern Seed Potato co., Raisio Potato Industry, Seed Potato Centre, Saarioinen and Estrella. Furthermore, data were collected by interviewing four seed potato producers that only purchase the registered seed from a variety representative (i.e., such that do not have a production contract with the variety representative). Farm-specific data were collected from 49 seed potato farms from around Finland. Based on the data obtained through the deep interviews, farms producing seed potato were divided into five categories based on their agreements: transaction, vertical integration, franchising, network agreement and advancement trade agreement.

\section{Transaction}

Figure 1 presents the vertical connections between the various agents on a transaction market-type seed potato market. The seed potato producers have an agreement with the marketing company (variety representative) on the marketing of seed potato. The total monetary amount of the sold seed potato is divided by the seed potato weight in kilograms produced by contract producers. The average price of seed potato thus obtained is paid by the marketing company to each producer of seed potato according to the seed potato kilograms they have produced, which have been inspected and deemed suitable as seed potato. The data of the inspected seed potato quantity packed by the cultivators used as the basis for the payment are obtained by the marketing company from the Finnish Plant Production Inspection Centre.

The seed potato producer stores, prepares for sale and packs the cultivated seed potato, has it inspected, and pays the inspection fees. The buyer of the seed potato (the food potato producer), pays for the seed potato only after the delivery to the marketing company. The seed potato marketing 


\section{AGRICULTURAL AND FOOD SCIENCE}

Vol. 16 (2007): 3-16

company pays the average price obtained for the seed potato to the seed potato producer, while the seed potato producer pays the marketing company a royalty and marketing fee for the sold quantities. The ellipse presented in Figure 1 with the dotted line presents the production agreement between the seed potato producer and the seed potato marketing company. The agreement does not extend to the food potato producer.
The agreement does not extend to the food potato producer. On the transaction market basis works $41 \%$ of Finland's seed potato market. The transaction market functions in a market-oriented way, where each agent attempts to maximize their own benefit. The seed potato marketing company is a principal offering an agreement to seed potato producers. The marketing company sees to the marketing and sale of the seed potato and attempts

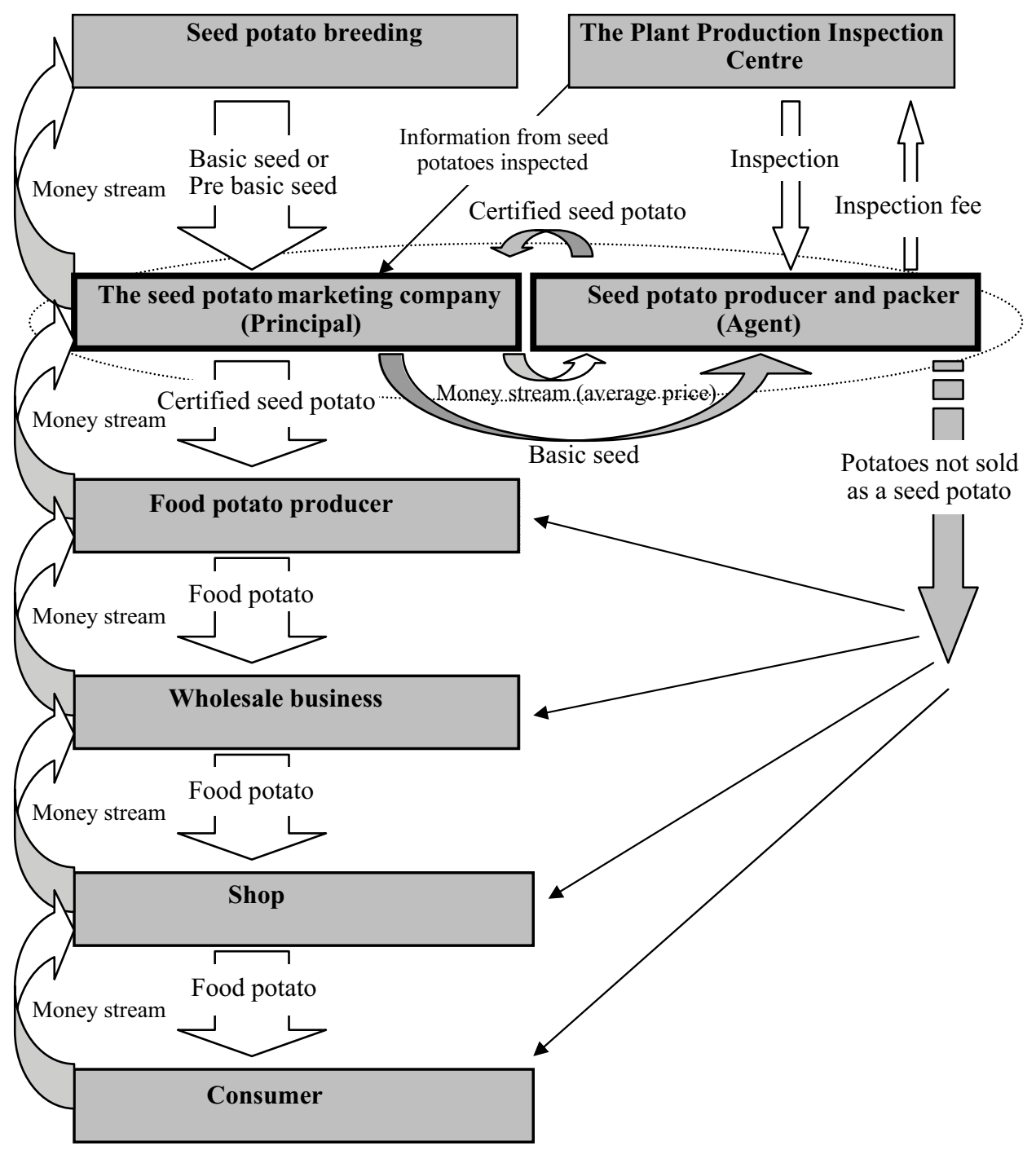

Fig. 1. Vertical connections between the various agents on a transaction market-type seed potato market. 
Tuomisto, J. Contract production and market uncertainty in potato production

to prevent competition between contract seed potato producers.

\section{Vertical integration}

The seed potato producer has an agreement with the principal that perfectly commits both parties in vertical integration. The principal provides the seed potato producer with almost all input, including the base seed, fertilizers, pesticides and packing materials and pays for all plant inspection fees. The price of the base seed to the seed potato producer is subsidized so that the seed size notwithstanding the seed cost per hectare would be equal. When buying the input for all contract seed and food potato farms, the principal can acquire the input at a lower cost than if each agent were to buy them directly. The average discount attained in joint pesticide purchases is approximately $15 \%$.

The principal purchases the entire crop from the seed potato farms. The crop is warehoused at the seed potato farm's own warehouse. The seed potato producer sorts the potato to two sizes and the principal pays the predetermined kilogram price for the seed potato. Also oversize and undersize potato not qualifying as seed potato, as well as the sorting waste, are delivered to the principal, who also pays for them at a predetermined price. The principal attempts to slightly oversize (objective 10\%) the seed potato production in comparison to the seed quantity required by the food potato producers. With this, the principal attempts to secure the availability of reasonably priced seed potato with different crops regardless of fluctuations in the crop. The principal's price control also aims at the seed potato producers producing larger seed.

Both, the seed potato producers and the food potato producers, as well as distributors and retailers, are included in the agreement. The marketing company acts as the principal that offers an agreement to the parties. The principal supervises the farm's operation and provides instructions and advice on carrying out the production at the farm. On the vertical-integration agreement model works $26 \%$ of Finland's seed potato production.
The vertical integration agreement is common in food potato industry and is centred at the marketing company. With the agreements, the principal attempts to secure the availability of high-quality seed and food potato and also secure the market all the way to the retail stores. The producers of seed and food potato can ensure the demand for the potato with the agreements, while the retailers can secure the availability of potato at a fixed, predetermined price. The marketing risk is transferred entirely to the principal.

\section{Franchising agreement}

The seed potato producer has an agreement with the principal that perfectly commits both parties in franchising agreement. The seed potato producer only acts as the farmer of the potato crop. The seed potato is delivered after harvest in the autumn to the principal's warehouse, and the principal pays a fixed, predetermined price for the raw seed potato quantity. The seed potato is sorted at the principal's warehouse to two size groups, but the farmer is paid the same fixed price per kilogram regardless of the seed size. The seed price is only paid, however, up to 24 metric tonnes per hectare, while the excess is remunerated at the price of food potato on the free market at the time of delivery, yet not more than the price of seed potato. The principal delivers all input to the seed potato farms. The seed potato producers and the seed potato marketing company do not have an agreement with food potato producers on the production of seed potato, and therefore the price and previous experiences transfer information in the vertical marketing chain. The franchising agreement model is centred at the seed potato producer. By centralising the packing functions to large units, fixed costs can be reduced. The marketing risk is transferred entirely to the principal. The franchising agreement reduces competition between seed potato producers.

The production agreement is founded between the seed potato producer and the seed potato marketing company. The agreement does not extend to the food potato producer. An agreement of this type covers 11 percent of Finland's seed potato 
market and is centred at the seed potato producer. The marketing company acts as the principal that offers an agreement to the seed potato producer. The principal supervises the farm's operation and provides instructions on carrying out the production at the farm.

\section{Network agreement}

The seed potato producer has an agreement with the principal on the production of seed potato in network agreement. The price of the seed potato is agreed upon prior to the planting of the seed potato. The seed potato producer warehouses and sorts the seed potato as well as prepares it for sale at the producer's farm. The principal pays the remuneration for the seed potato in April, when the seed potato goes directly to food potato farms that have a contractual relationship with the principal. The price of the base seed is subsidized so that the price is always the same to the seed potato producer regardless of the seed size. This agreement model is typical to the food potato industry.

A network agreement covers eight percent of Finland's seed potato market. A network agreement is almost similar to vertical integration but is less committing to the parties, more centred at the refiner, and the quality criteria for seed potato are lower. The principal does perceive it a great loss if a seed potato producer rejects an agreement offered to the producer. An agreement with the distributor and the retail stores are more important to the principal than an agreement with the seed potato producers.

\section{Advancement trade agreement}

The seed potato producer acts as the principal, offering food potato producers an agreement on the trade of seed potato at a predetermined price in advancement trading of seed potato.

The seed potato producer sorts the potatoes to two seed size groups. A fixed price is negotiated with the food potato producers for these size groups prior to the planting of the seed potato.
The payment for the seed is not, however, made until after the delivery of the seed potato. The food potato producers commit themselves to purchase the entire seed crop from the seed potato producer. If, due to crop failure, the seed potato producer cannot deliver the agreed-upon seed quantity, the seed potato producer has no liability to compensate. The seed potato producer has an agreement with the variety representative on the delivery of the base seed to the seed potato producer. The seed potato producer pays the variety representative a royalty and variety representation fee on the sold seed potato quantity. The variety representative can check the sold seed potato quantities from the Plant Production Inspection Centre. According to the research material, an advancement trade agreement covers $14 \%$ of Finland's seed potato market.

\section{Methods}

Based on Salanié (1997) and Kuwornu (2004), there is a theoretical foundation on how the market uncertainty of potato production affects on whether food potato producers purchase the certified seed or use farm-saved seed. In this section implementation is carried out as follows: First, the volumes certified as seed potato were determined. Next quantities that variety representatives or organizations acting with the variety representatives' licence had had cultivated in 1997-2000 were determined. Then, it was surveyed how big a share of potato qualifying as seed potato was used as something else than seed potato, what each organization's price of the seed potato to food potato producers is, and what was the average price paid to seed potato producers, considering that part of the seed potato crop that was used as something else than seed potato. Thus, the market uncertainty in the various seed potato producer organizations was solved. After this, farm models for two farm sized, with 15 (farm model A) and 30 (farm model B) hectares of seed potato, were devised to suit the business budgets (see also: Turunen 2001), and it was determined how contract production affects the income, profitability and liquidity of the farms, and what the motives and 
restrictions of the various parties are in increasing and developing contract production (Uusitalo and Pietola 2001 used similar research method by their study on Contracts in the Finnish hog farms).

The profitability of seed potato production in the various contract models (the benefit for seed potato producer in the various contract models) was inspected with net profit calculations (1) and profitability coefficients (2):

$\pi_{\text {AVERAGE }}=\frac{\sum_{t=1}^{T}\left(\sum_{i=1}^{n} p_{i} y_{i}-\sum_{j=1}^{m} w_{j} x_{j}+\sum_{k=1}^{z} s_{k}\right)}{T}$

$R_{A V E R A G E}=\frac{\sum_{t=1}^{T}\left(\frac{a}{l+r}\right)}{T}=\frac{\sum_{t=1}^{T}\left(\frac{\pi+l+r}{l+r}\right)}{T}$

The average net profit $\pi$ in the various contracts is an average subtraction between sum of total returns and sum of total costs plus sum of total support in the contracts. When we ignore share of value of farmers own workload $l$ and capital interests $r$ from the net profit, we can achieve share of the agricultural income $a$ by sum of value of farmers own workload $l$ and capital interests $r$, we can achieve profitability ratio $R$ of seed potato producer in the various contracts. When we sum all profitability ratios and divide the sum by years $T$ our study, we can achieve an average profitability ratio.

The benefit of a food potato producer in the contract production of seed potato cannot only be measured by the price of seed potato, as the various organizations offering seed potato produce different sizes of seed. The seed cost of a food potato hectare is a better indicator of benefit of a food potato producer. The seed cost of a food potato hectare can be calculated by the following formula:

$C_{R i}=\frac{\sum_{t=1}^{T} \sum_{i=1}^{n} k_{i t} z_{i} \frac{10^{5}}{\alpha_{i} \beta_{i}} w_{i t}}{T}$

Thus, the average seed cost of a food potato hectare for the crop years 1997-2000, $C_{R i}\left(€ \mathrm{ha}^{-1}\right)$, has been calculated by multiplying the required seed quantity (tubers ha ${ }^{-1}$ ), obtained from the planting distance $\alpha_{i}(\mathrm{~cm})$ and spacing $\beta_{i}(\mathrm{~cm})$ of each variety and seed size, with the seed weight $z_{i}$ (g per unit) and by multiplying the result thus obtained with the average deflated seed sale price $w_{i t}$ (cents $\mathrm{kg}^{-1}$ ) of 2000, considering the share of seed produced with each of the contract models in the different years, $k_{i t}(k=0, \ldots, 1$, i.e., $\Sigma k=1)$ in the various seed size classes $(I=1 \ldots \mathrm{n})$ and by dividing the sums hence obtained with the number $T$ of years $(t=1, \ldots, m)$ inspected.

\section{Results}

\section{Adverse selection problem}

The possibility of a food potato producer to use noncertified seed as the seed causes market uncertainty for the seed potato producer. Seed potato producers in the transaction market faced the market uncertainty problem. For example, during the growing year 2000, only 65.4 percent of qualifying seed of the total gross crop of 24 tonnes was sold as seed. The remainder was sold as food potato or waste potato at prices lower than the production cost of seed potatoes.

Figure 2 illustrates the effect of food potato price on the selling price of seed potato and the price received by seed potato producer in the transaction market. The higher the difference between the seed's selling price and the average price received by the seed potato producer, the higher a share of seed potato is sold to non-seed use. The difference of seed potato's selling price and the average price received by the seed potato producer clearly correlates with the price of food potato. The lower the price of food potato, the higher the difference of seed potato's selling price and the average price received by the seed potato producer and, consequently, the higher the uncertainty in the seed potato market. The correlation coefficient between the price received by the seed potato producer and the price of food potato is 0.93 for small seed size and 0.81 for a larger seed size for the period 1997-2001. 


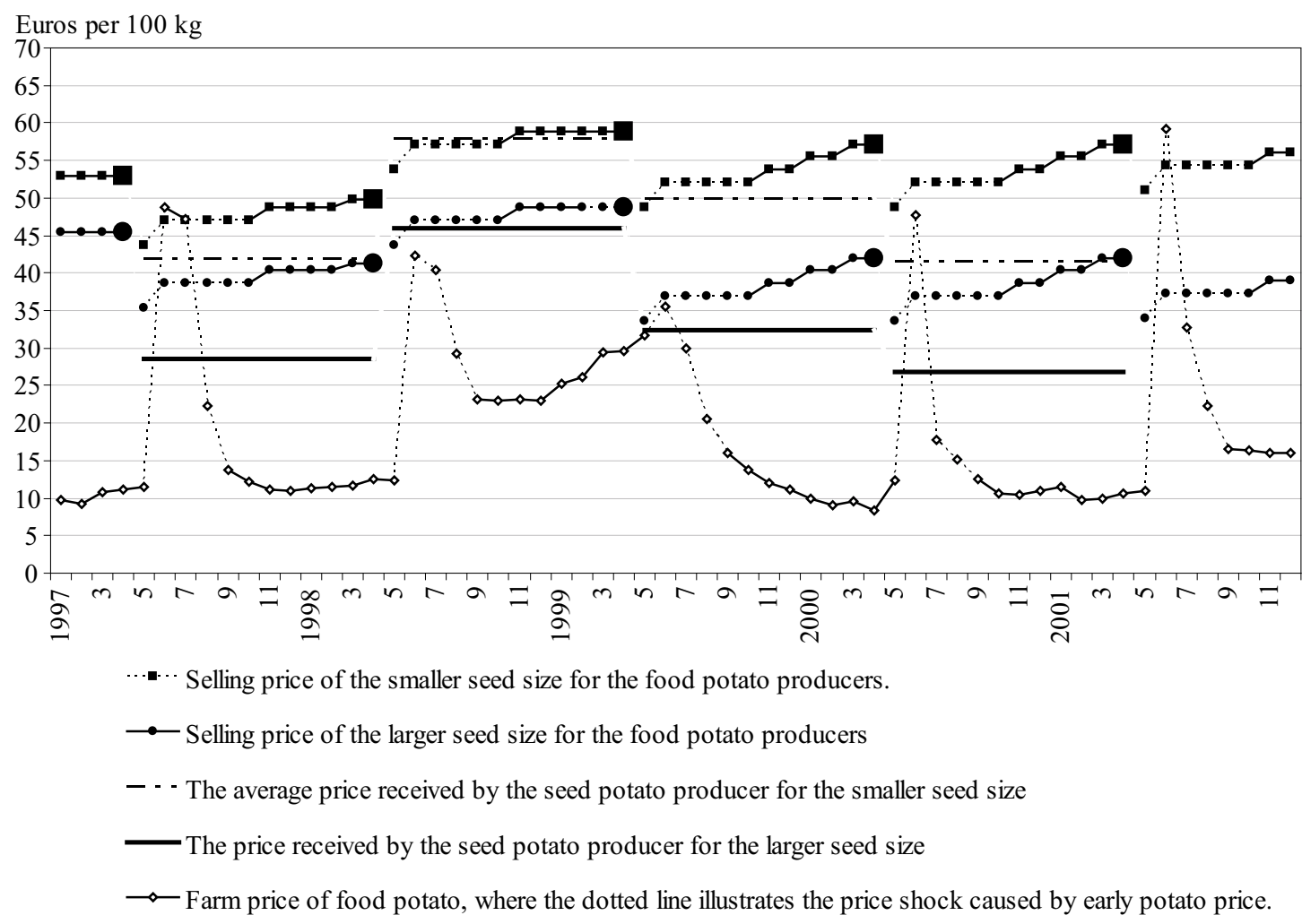

Fig. 2. The impact of the producer price of food potato in the free market on the price paid by the food potato producer and received by the seed potato producer.

On the transaction market, the fluctuation of the price of food potato strongly affects the profit fluctuations and uncertainty of seed potato production and, subsequently, the profitability. The profit fluctuation could be reduced with contract production. Figure 3 illustrates the net profit of seed potato production and the earnings with different contract models on the farm with 15 hectare of seed potato in the crop years 1997-2000.

In no contract model could the seed potato producer attain positive average profit in 1997-2000. Only in the crop year 1998, when the price of food potato also was higher, could seed potato producers active in the transaction market attain positive net profit. The greatest net profit fluctuation between the different years occurred in the transaction market.
Despite the increased market price of seed potato caused by the crop failure year 1998, positive net profit was not attained on the transaction market during the inspection period in either of the farm models (Table 1, Fig. 4). Also the earnings from work remained lower at the transaction market than in the vertical integration and franchising agreement models. The exceptionally low crop of 1998 resulted in dramatic decrease of income to farms working with a network agreement, as the producer could not benefit from the profits brought about by the high market price. With the network agreement model, the cumulative net profit for the crop year 1998-1999 decreased rapidly, in particular if the profits accrued are compared to the net profit of seed potato farms that acted on the transaction market in the same year (Fig. 
Tuomisto, J. Contract production and market uncertainty in potato production

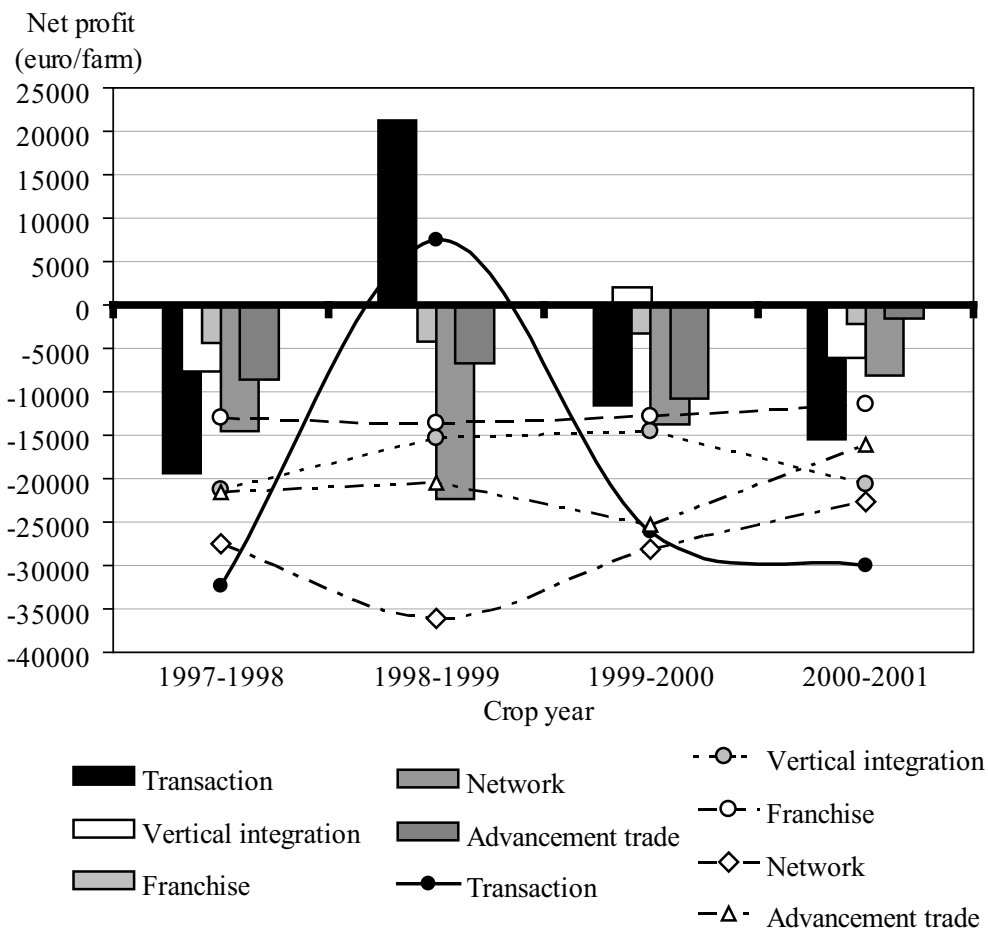

Fig. 3. The net profit (loss) on farms with 15 hectares of seed potato with the different contract models in growing years 19972000. In the figure, farmers work earnings are indicated as bars and the net profit as lines.
4). The lowest net loss was attained through the franchising model, where the seed potato producer only acts as the cultivator of seed potato for the principal and the principal stores the potato in its own warehouse (Table 1).

Table 2 presents the euro-difference of seed potato cost of food potato producers and the ratio between the various contract models compared to the hectare-specific seed cost formed with seed purchased from the transaction market. The higher the ratio, the higher the food potato producer's benefit is with the seed cost from the contract model. The table also presents the average net profit of the crop years 1997-2000 obtained by seed potato producers with the various contract models and the euro-difference and relative difference of the net profit of the various contract models compared to the transaction market. The higher the ratio, the higher the seed potato producer's benefit is from the contract model.

Results in Table 2 indicate that no contract model provided seed potato producers with average positive net profits, and profitability ratios for seed potato farms stayed below one. Only farms with 30 hectare of seed potato show profits equal to other branches of agricultural production. The profitability of farms increases in proportion to farm size. Production costs per kilo of seed potato produced were 8.8 per cent lower for farms with 30 hectare of seed potato than for farms with 15 hectare of seed potato on the transaction market. Result is parallel than in early study done by Turunen 2001, if only Turunen achieved smaller difference between farm models. Furthermore net losses were smaller by Turunen 2001, because he has excluded effects of market uncertainty on his study.

The opportunity cost of the agreements is manifested as the profit of the different agreements for both the seed potato and food potato producer. The opportunity cost is presented in Table 2 . The research problem in this research was that each company that markets seed potato only has one type of agreements. The companies form a local monopoly, which makes it difficult to change the agreement type. 
Vol. 16 (2007): $3-16$

Table 1. Impact of agreements on the cumulative work earnings ( $€$ per farm) and net profit ( $€$ per farm) with 15 and 30 seed potato hectare farms during the crop years $1997-2000$.

\begin{tabular}{|c|c|c|c|c|c|}
\hline Farm model & Agreement type & 1997 & 1998 & 1999 & 2000 \\
\hline \multicolumn{6}{|c|}{15 ha } \\
\hline \multicolumn{6}{|c|}{ Cumulative work earnings } \\
\hline & Transaction market & -19449 & 1728 & -9849 & -25355 \\
\hline & Vertical integration & -7617 & -7799 & -5828 & -11881 \\
\hline & Franchising agreement & -4326 & -5872 & -11895 & -14039 \\
\hline & Network agreement & -14601 & -36988 & -50724 & -58902 \\
\hline & Advancement trade & -8660 & -15439 & -26216 & -27701 \\
\hline & Transaction market & -32365 & -24885 & -50923 & -80978 \\
\hline & Vertical integration & -21217 & -36519 & -50984 & -71671 \\
\hline & Franchising agreement & -12963 & -26536 & -39393 & -50774 \\
\hline & Network agreement & -27517 & -63601 & -91798 & -114524 \\
\hline & Advancement trade & -21576 & -42051 & -67290 & -83324 \\
\hline
\end{tabular}

30 ha

Cumulative work earnings

Transaction market
Vertical integration
Franchising agreement
Network agreement
Advancement trade

$\begin{array}{rrrr}-20428 & 43043 & 38543 & 24968 \\ 1466 & 16742 & 33977 & 38242 \\ 2099 & 4778 & 9185 & 15534 \\ -10509 & -34501 & -43723 & -42779 \\ 2511 & 10070 & 7183 & 21722\end{array}$

Cumulative net profit

\begin{tabular}{|c|c|c|c|c|c|}
\hline & Transaction market & -40061 & 3570 & -20837 & -54332 \\
\hline & Vertical integration & -18167 & -22731 & -26103 & -41758 \\
\hline & Franchising agreement & -9133 & -17944 & -25117 & -30047 \\
\hline & Network agreement & -30142 & -73974 & -103103 & -122079 \\
\hline & Advancement trade & -17122 & -29403 & -52197 & -57578 \\
\hline Consumer price index $(1995=100)$ & & $-101,8$ & $-103,2$ & $-104,4$ & -108 \\
\hline
\end{tabular}

\section{Moral hazard problem}

In this paper moral hazard illustrates situation, where some of the agents (seed potato producers) not adhere to an agreement. Figure 5 illustrates food potato price in the transaction market and seed potato prices in the fixed price contracts. In Figure 5 the dotted line for the selling price of seed potato refers to advancement trade executed with forward pricing at a time when no potato crop to market exists. The large dot is the time of delivery of seed potato to the food potato producer. Whenever the price of food potato is higher than the price of seed potato, it may be tempting for the seed potato producer to sell seed potato as food potato in breach of contract.

Table 3 and Figure 6 illustrate effect of the moral hazard for the accumulating net profit of the seed potato producer in the fixed price contract production. In the case of moral hazard is assumed that seed potato producer sell 10 percent of seed potato crop as food potato and principal who has offered contract can not monitor action on the seed potato producer. 


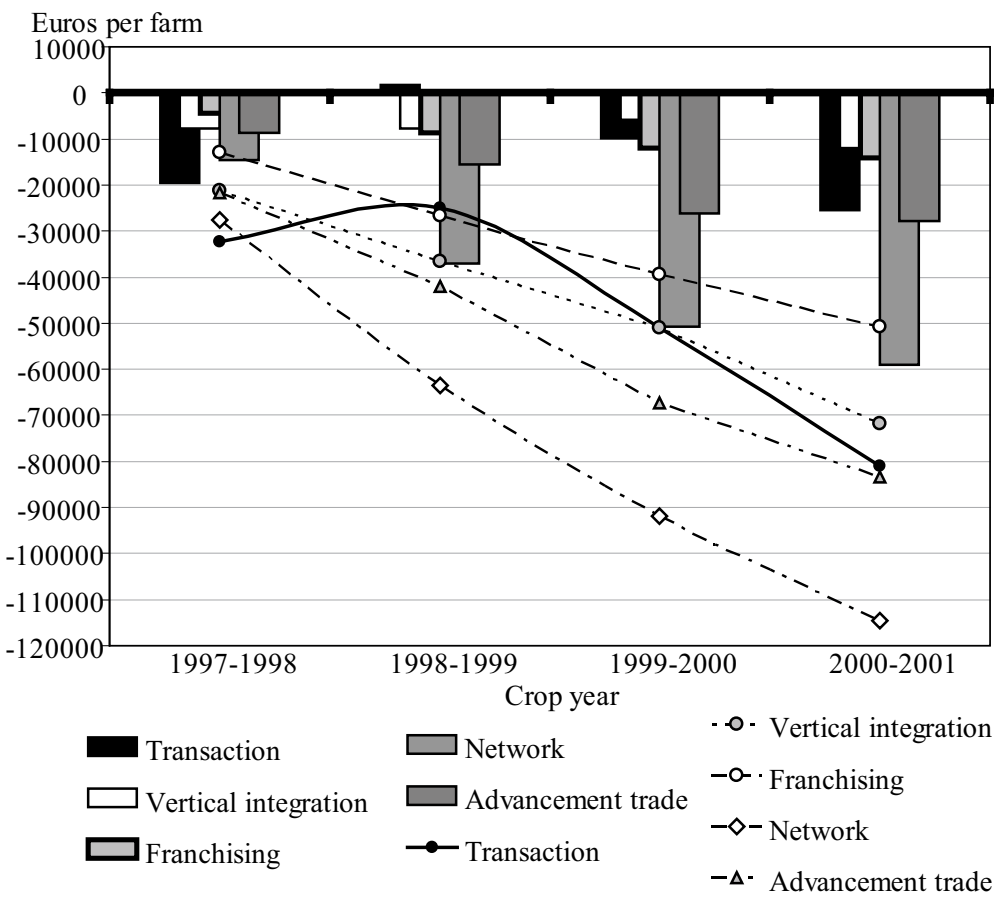

Fig. 4. Cumulative work earnings and net profit in a farm of 15 seed potato hectares with the different contract models in the crop years 1997-2000.

Table 2. The euro-difference of seed potato cost of food potato producers and the ratio between the various contract models compared to the hectare-specific seed cost formed with seed purchased from the transaction market in the crop years 1997-2000.

\begin{tabular}{|c|c|c|c|c|c|c|}
\hline $\begin{array}{l}\text { Average } \\
\text { seed cost of } \\
\text { food potato } \\
\text { hectare } \\
(€ \text { per ha) }\end{array}$ & $\begin{array}{l}\text { Differ- } \\
\text { ence to the } \\
\text { transaction } \\
\text { market }\end{array}$ & Ratio & $\begin{array}{l}\text { Average } \\
\text { net profit of } \\
\text { seed potato } \\
\text { producers } \\
\text { (euros per } \\
\text { farm) }\end{array}$ & $\begin{array}{l}\text { Differ- } \\
\text { ence to the } \\
\text { transaction } \\
\text { market }\end{array}$ & Ratio & $\begin{array}{l}\text { Profitability coefficient } \\
\text { of seed potato produc- } \\
\text { tion as the arithmetic } \\
\text { average of the growing } \\
\text { years } 1997-2000\end{array}$ \\
\hline
\end{tabular}

15 ha

Transaction

Vertical integration

Franchise

Network agreement

Advancement trade

1276

944

1389

642

1105

0
-332
113
-634
-171

100

135

$-20244$

$-17918$

$92-12693$

$199-28631$

$115-20831$

$\begin{array}{rr}0 & 100 \\ 2327 & 113 \\ 7551 & 159 \\ -8387 & 71 \\ -587 & 97\end{array}$

0.31

0.42

0.39

0.03

0.29

30 ha

\section{Transaction}

Vertical integration

Franchise

Network agreement

Advancement trade

\begin{tabular}{rrrr}
1276 & 0 & 100 & -13583 \\
944 & -332 & 135 & -10440 \\
1389 & 113 & 92 & -7512 \\
642 & -634 & 199 & -30520 \\
1105 & -171 & 115 & -14395 \\
\hline
\end{tabular}

$\begin{array}{rr}0 & 100 \\ 3143 & 130 \\ 6071 & 181 \\ -16937 & 45 \\ -812 & 94\end{array}$

0.72

0.79

0.78

0.36

642

$-171$

$115-14395$

0.70 
Vol. 16 (2007): 3-16

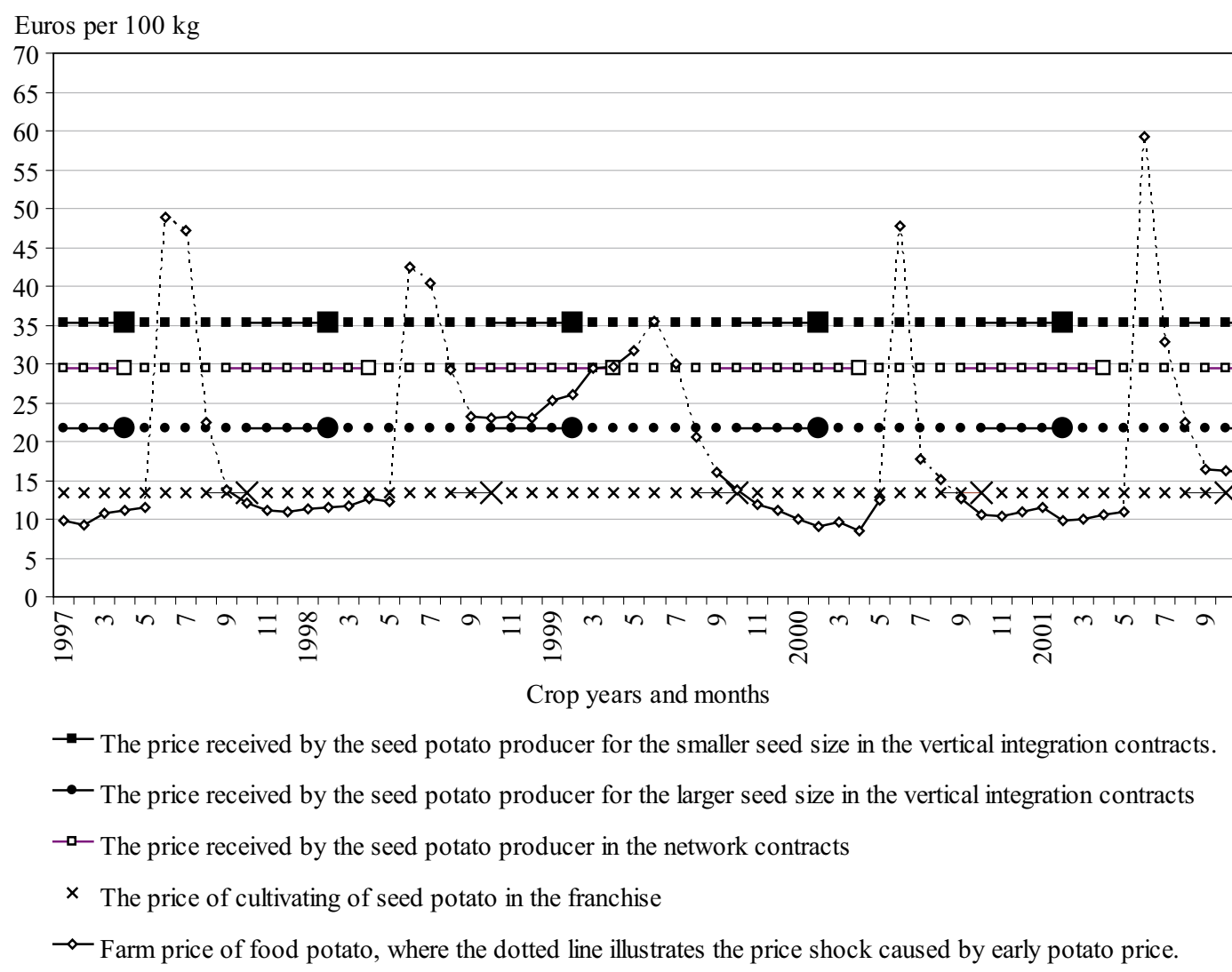

Fig. 5. Food potato price in the transaction market and seed potato prices in the fixed price contracts in growing years 1997-2001.

\section{Conclusions}

Results of this study indicate that no contract model provided seed potato producers with average positive net profits, and profitability ratios for seed potato farms stayed below one. Only farms with 30 hectare of seed potato show profits equal to other branches of agricultural production. The profitability of farms increases in proportion to farm size. Production costs per kilo of seed potato produced were 8.8 per cent lower for farms with 30 hectare of seed potato than for farms with 15 hectare of seed potato on the transaction market. According to the study, the lowering of seed potato price does not alone increase the long-term demand of seed potato but also contract production is required to stabilize the demand for seed potato.
Seed potato producers working with fixed-price advancement trade can sell seed potato at a price 13 percent lower than without the agreement - without decreasing the profitability of seed potato production. Kuwornu et al. (2004) reached similar results in Dutch potato marketing, albeit margin of the profits between advancement trade (future marketing) and without agreement (spot marketing) is even greater.

The more consistent the supply chain is, the lower the market uncertainty and also the lower the possible price of seed potato. To reduce the market uncertainty of seed potato, the food potato producer should be a contract party in the chain. An agreement between seed potato producers and the seed potato marketing company alone hardly reduce the market uncertainty. 


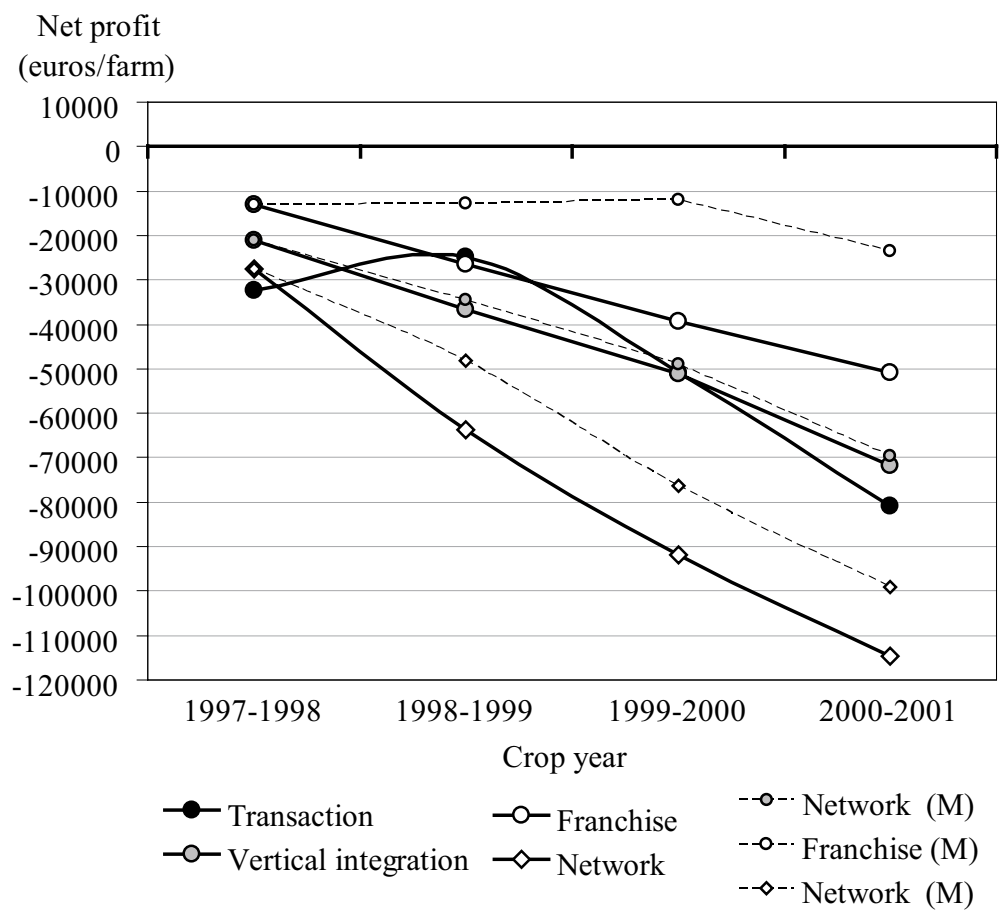

Fig. 6. Effect of the moral hazard for the cumulative net profit (loss) of the seed potato producer in the fixed price contract production in a farm of 15 seed potato hectares. Accumulate net profit of the dif-ferent contract models are marked as continuous lines and correspondingly accumulate net profit in status of the moral hazard (M) is market as broken lines.

Table 3. Effect of the moral hazard (M) for the cumulative net profit of the seed potato producer in the fixed price contract production in a farm of 15 seed potato hectares

\begin{tabular}{lcccc}
\hline & \multicolumn{4}{c}{ Crop year } \\
\cline { 2 - 4 } & $1997-1998$ & $1998-1999$ & $1999-2000$ & $2000-2001$ \\
\hline Cumulative net profit (Euros per farm) & & & & \\
Transaction & -32365 & -24885 & -50923 & -80978 \\
Vertical integration & -21217 & -36519 & -50984 & -71671 \\
Franchise & -12963 & -26536 & -39393 & -50774 \\
Network & -27517 & -63601 & -91789 & -114524 \\
& & & & \\
Cumulative net profit under the moral hazard & & & & \\
(Euros per farm) & -21217 & -34423 & -48887 & -69575 \\
Vertical integration (M) & -12963 & -12875 & -12048 & -23430 \\
Franchise (M) & -27517 & -48202 & -76399 & -99126 \\
Network (M) & -101.8 & -103.2 & -104.4 & -108 \\
Consumer price index (1995=100) & & & & \\
& & & & \\
Margin & & & 2097 & $-2.90 \%$ \\
Vertical integration (M) & & & 15344 & $-53.90 \%$ \\
Franchise (M) & & &
\end{tabular}


It is possible to add factors that increase the production cost of seed potato to contract production. This is then compensated to the seed producer in the price of the seed potato. An example of this is when the party offering the contract wishes the seed potato producer to use a production effort or method that the seed potato producer would consider too expensive and would not perceive a benefit from it. It is also possible to include collective purchases of production efforts in contract production so that even smaller contract-production farms can enjoy the least expensive production effort prices. Cost compensation linked to contract production can, however, cause moral hazard problem; the seed potato producer can sell the seed potato as food potato in violation of the agreement. Whenever the price of food potato is higher than the price of seed potato, it may be tempting for the seed potato producer to sell seed potato as food potato in breach of contract. Contract production can be a means to control the needs of the various parties to the contract but it will be up to the objectives of the party offering the contract, which party in the potato chain most benefits from the contract production. The companies form a local monopoly, which makes it difficult to change the agreement type.

\section{References}

Anderson, J.R. 1973. Risk aversion and polynomial preference. Australian Economics Paper 12, 21: 261-262.

Gravelle, H. \& Rees, R. 1992. Microeconomics. Second edition. United Kingdom: Logman Group UK Limited. 752 p.

Jalonoja, K. 2001. Perunamarkkinoiden toimivuus Suomessa. Abstract: Whole sales market for fresh potatoes in Finland. MTT, Economic Research, Working Papers 5/2001. 34 p.

Knoeber, C.R. \& Thurman 1995. "Don't count your chickens...": risk and risk shifting in the broiler industry. American Journal of Agricultural Economics 77: 486-496.

Kuwornu, J.K.M., Kuiper, W.E., Pennings, J.M.E. \& Meulenberg, M.T.G. 2004. Agency theory, futures markets and risk shifting in commodity marketing channels. In: Bremmers, H.J. et al. (eds.). Dynamics in chains and network. Wageningen Academic Publishers, Wageningen University, The Netherlands. p. $510-517$.

Martin, L.L. 1997. Production contracts, risk shifting, and relative performance payments in the pork industry. Journal of Agricultural \& Applied Economics 29, 2: 267-278.

Milgrom, P. \& Roberts, J. 1992. Economics, organization \& management. Standford University. New Jersey: Prentice Hall, Upper Saddle River. 621 p.

Molho, I. 1997. The economics of information. Lying and cheating in markets and organizations. Oxford. UK. Blackwell Publishers Ltd. $262 \mathrm{p}$.

Redman, B.J. \& Redman, J.C. 1981. Microeconomics: resource allocation and price theory. Westport. Connecticut. USA: The Avi Publishing Company INC. 294 p.

Salanié, B. 1997. The economics of contracts. A Primer. Cambridge: The MIT Press. $223 \mathrm{p}$.

Tuomisto, J. 2003. Siemenperunan sopimustuotanto Suomessa. Abstract: Contracting in the Finnish seed potato market. MTT Agrifood Research Reports 22. 109 p.

Turunen, H. 2001. Perunantuotannon tilamallit. Abstract: Farm models for potato production. MTT, Economic Research, Working Papers 23/2001. 58 p.

Uusitalo, P. \& Pietola, K 2001. Teknologiavalinnat ja sopimukset Suomen sikatiloilla. Abstract: Contract in the Finnish hog farms. Agricultural Economics Research Institute, Research reports 149/2001. $114 \mathrm{p}$.

\title{
SELOSTUS
}

\section{Sopimustuotanto siemenperunan markkinahinnan vakauttajana}

\author{
Jussi Tuomisto \\ MTT Taloustutkimus
}

Korkealaatuinen siemenperuna on tärkeä tekijä, kun tuotetaan satoisaa ja hyvälaatuista ruokaperunaa. Ruokaperunantuottaja voi käyttää istutukseen joko sertifioitua siemenperunaa tai siitä yhden kerran lisättyä tilan omaa siementä.

Perunasatojen suuruus ja ruokaperunan hinta vaihtelevat vuosittain. Ylituotantotilanteessa ruokaperunantuottajat käyttävät siemeneksi mieluummin oman tilan ylijäämäperunaa kuin hankkivat siemenet siemen- perunantuottajalta. Kun perunasato on ollut huono ja perunan hinta korkea, ruokaperunantuottajat sen sijaan myyvät koko sadon ruokaperunaksi ja ostavat enemmän sertifioitua siementä. Tämän vuoksi sertifioidun siemenen kysyntä vaihtelee ja joinain vuosina kysytyimmät siemenperunalajikkeet loppuvat kesken, kun taas toisina siemenperunasta on ylitarjontaa. Ylitarjontatilanteessa siemeneksi kelpaavaa perunaa joudutaan myymään ruokaperunaksi tai jäteperunaksi tuotantokustan- 
nukset alittavalla hinnalla. Kysynnän ja tarjonnan vaihtelut lisäävät siemenperunan tuotantokustannuksia ja siten myös nostavat sen markkinahintaa pitkällä aikavälillä.

Tässä tutkimuksessa selvitetään, voidaanko siemenja ruokaperunantuottajien välisen sopimustuotannon avulla vähentää markkinaepävarmuutta, parantaa siemenperunakaupan osapuolten hyvinvointia ja samalla lisätä koko perunaketjun tehokkuutta. Tavoitteena on tunnistaa siemenperunamarkkinoiden keskeiset ongelmat, pohtia yhteistyön merkitystä ja laajuutta ruokaperunaketjussa sekä selvittää, miten sopimuksilla voidaan alentaa hintariskiä ja markkinaepävarmuutta. Tutkimuksessa tarkastellaan lisäksi, miten sopimustuotannon avulla voidaan kehittää kannustimia, joilla on eri osapuolten kannalta positiivisia vaikutuksia.

Tutkimusaineisto kerättiin siemenperunan lajikeedustajilta ja markkinointiyhtiöiltä. Tietoja saatiin myös Kasvintuotannon tarkastuskeskuksesta, Maatalouden tietopalvelukeskuksesta sekä 49 siemenperunatilalta eri puolelta Suomea. Aineiston perusteella luotiin tilamallit kahdelle erikokoiselle tilalle: toisen siemenperunan viljelypinta-ala on 15 , toisen 30 hehtaaria. Lisäksi selvitettiin, miten sopimustuotanto on vaikuttanut tilojen tuloihin, kannattavuuteen ja maksuvalmiuteen ja millaisia ovat eri osapuolten motiivit ja rajoitteet sopimustuotannon lisäämisessä ja kehittämisessä.

Yksistään hinnan aleneminen ei lisää siemenperunan kysyntää pitkällä aikavälillä. Tarvitaan myös sopimustuotantoa vakauttamaan kysyntää. Kiinteähintaisessa ennakkokaupassa toimivat tuottajat voisivat myydä siemenperunaa 13 prosenttia halvemmalla kuin ilman sopimusta kannattavuuden kuitenkaan heikentymättä. Mitä yhtenäisempi tarjontaketju on, sitä vähäisempi on markkinaepävarmuus ja sitä alhaisempi voisi olla myös hinta. Pelkkä tuottajan ja markkinointiyhtiön välinen sopimus vähentää siemenperunan markkinaepävarmuutta kuitenkin vain hieman. Jotta markkinaepävarmuus vähenisi merkittävästi, on tärkeää, että ruokaperunantuottaja on mukana sopimusosapuolena.

Sopimustuotantoon voidaan liittää myös tuotantokustannuksia korottavia tekijöitä, jotka korvataan siementuottajalle siemenperunan hinnassa. Näin voidaan toimia esimerkiksi silloin, kun sopimusta tarjoava osapuoli haluaa siemenperunantuottajan käyttävän sellaista tuotantopanosta tai tuotantotapaa, jota tuottaja pitää liian kalliina ja josta hän ei koe itse hyötyvänsä. Sopimustuotantoon voidaan kytkeä myös tuotantopanosten yhteisostot, jolloin pienetkin sopimustuotantotilat pääsevät hyötymään edullisista hinnoista. Esimerkiksi kasvinsuojeluaineet saatiin yhteisostoilla 15 prosenttia edullisemmin. Sopimustuotantoon liitetty kustannuskompensaatio saattaa kuitenkin aiheuttaa niin sanotun peitellyn toiminnan ongelman: siemenperunantuottaja voi myydä siemenperunan sopimuksen vastaisesti ruokaperunaksi silloin, kun ruokaperunan hinta on siemenperunan hintaa korkeampi.

Sopimustuotannon avulla voidaan tehostaa tarjontaketjua ja kontrolloida eri sopijaosapuolten tarpeet. Sopimusta tarjoavan osapuolen tavoitteista kuitenkin riippuu, mikä perunaketjun osapuolista hyötyy sopimustuotannosta eniten. 